\title{
Dispute Settlement in the Law of the Sea Convention: The Military Activities Exception
}

\author{
Mark Weston Janis \\ University of Connecticut School of Law
}

Follow this and additional works at: https://opencommons.uconn.edu/law_papers

Part of the Admiralty Commons, International Law Commons, and the Military, War, and Peace Commons

\section{Recommended Citation}

Janis, Mark Weston, "Dispute Settlement in the Law of the Sea Convention: The Military Activities Exception" (1977). Faculty Articles and Papers. 245.

https://opencommons.uconn.edu/law_papers/245 


\section{HEINONLINE}

Citation: 4 Ocean Dev. \& Int'I L. 511977

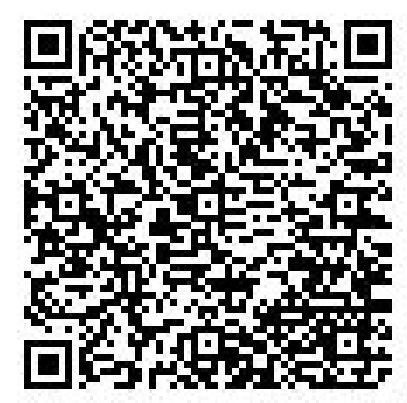

Content downloaded/printed from HeinOnline (http://heinonline.org) Mon Aug 15 16:56:25 2016

-- Your use of this HeinOnline PDF indicates your acceptance of HeinOnline's Terms and Conditions of the license agreement available at http://heinonline.org/HOL/License

-- The search text of this PDF is generated from uncorrected OCR text.

-- To obtain permission to use this article beyond the scope of your HeinOnline license, please use:

https://www.copyright.com/ccc/basicSearch.do?

\&operation $=$ go\&search $T y p e=0$

\&lastSearch $=$ simple \&all=on\&titleOrStdNo $=0090-8320$ 


\title{
Dispute Settlement in the Law of the Sea Convention: The Military Activities Exception
}

\author{
MARK W. JANIS*
}

\begin{abstract}
This paper considers the military activities exception in the settlement of disputes part of the Law-of-the-Sea Conference's Informal Single Negotiating Text. It notes that although the exception, on its face, seems to favor naval powers, in practice it would not. The emerging rules of the law of the sea are favorable to naval operations and it is more likely that the military activities exception would be used by coastal states resisting superpower naval activities. The military activities exception will remove activities from dispute settlement procedures which are almost certainly in need of peaceful resolution.
\end{abstract}

The most concrete result of eight years of law-of-the-sea negotiations is the Informal Single Negotiating Text which issued from the diplomatic discussions leading up to and including the 1975 Geneva session of the United Nations' Third Conference on the Law of the Sea (LOS III). ${ }^{1}$ The Informal Single Negotiating Text consists of three substantive parts each prepared by one of the chairmen of the three main committees of the Conference and a fourth part concerning dispute settlement presented by the co-chairmen of the Informal Working Group on Settlement of Disputes. ${ }^{2}$ Although the president of the conference has characterized the Informal Single Negotiating Text as merely a "procedural device" which will "only provide a basis for negotiation,"3 the four parts of the Text may very well be in the shape of things to come and should be discussed and, when necessary, criticized so that the emerging order of the oceans best facilitates the uses of the seas by all states with a minimum amount of conflict.

*Mark W. Janis is a J.D. candidate at Harvard Law School, Cambridge, Massachuset ts. 
The work of LOS III has been authoritatively presented in three articles co-authored by the Chief of the U.S. Delegation, Ambassador John R. Stevenson, and the U.S. Representative in Committee II, Bernard H. Oxman. ${ }^{4}$ This paper does not attempt to duplicate that record. Nor does the paper venture to cover the ground ably covered by the two articles on settlement of disputes written by members of the Informal Working Group on Settlement of Disputes, one by the Rapporteur, Professor Louis B. Sohn, and another by Co-Chairman A. O. Adede of Kenya. ${ }^{5}$

This paper is focused on a single clause of the settlement of disputes section of the Informal Single Negotiating Text: Part IV, Article 18, Section 2(c). This clause is within a section that begins:

When ratifying the present Convention, or otherwise expressing its consent to be bound by it, a Contracting Party may declare that it does not accept some or all of the procedures for the settlement of disputes specified in the present Convention with respect to one or more of the following categories of disputes: ${ }^{6}$

Article 18 , Section $2(\mathrm{c})$ is the third of four such exceptions which may be made to dispute settlement procedures. It concerns:

Disputes concerning military activities, including those by Government vessels and aircraft engaged in non-commercial service, it being understood that law enforcement activities pursuant to the present Convention shall not be considered military activities. ${ }^{7}$

Although Article 18, Section 2(c) is only one short element among many others in the Informal Single Negotiating Text, it is an especially crucial clause. Military activities have been one of the maritime interests which the great powers have been particularly diligent in protecting in the law-of-the-sea debate. ${ }^{8}$ Should the United States support the retention of Article 18, Section 2(c) in the Law-of-the-Sea Convention? If the clause is retained, should the United States elect the military activities exception? This paper argues that the United States should do neither.

Two analyses follow. First, the military activities exception is examined in context and compared with other military exceptions in other treaties. Second, the implications of Article 18, Section 2(c) for U.S. policy are considered and the conclusion is drawn that the clause poses many more problems than it is worth.

\section{The Military Activities Exception} in the Informal Single Negotiating Text

Article 18, Section 2(c) is part of an article which seems to represent the compromise position between those favoring compulsory dispute settlement in 
all cases and those favoring a policy permitting some exceptions. Although the working papers of the Informal Working Group on the Settlement of Disputes have not been published, ${ }^{9}$ some background to these negotiations has been provided in the articles by Sohn and Adede. Unfortunately, neither considers Article 18 in any depth, both devoting about two pages of text to it and most of this is given to verbatim rendition of the various proposals leading up to Article $18 .^{10}$ Still, the two articles are interesting both for what they have in common and the ways in which they differ. Sohn's is the earlier piece. He reports that there were three points of view-no exceptions permitted, exceptions to some or all parts of the Convention or to some dispute settlement procedures permitted, or only some explicitly specified exceptions permitted. ${ }^{11}$ Although Sohn does not name his own preference, the language of the article implies that he himself prefers the first option:

Some delegations believe that the integrity of the compromise package to be embodied in the Law-of-the-Sea Convention needs to be preserved at all cost and that effective dispute settlement provisions are needed, applicable without exception to all parts of the Convention. ${ }^{12}$

Adede also finds three points of view about exceptions to dispute settlement procedures, but they are slightly different than those of Sohn, to wit: no exceptions permitted, a limited category of exceptions permitted, or exceptions for "any dispute relating to a matter which falls within the national jurisdiction of a coastal state." 13 Although Adede seems to favor his middle (Sohn's last) option, he stresses the need:

to protect coastal states from constant harassment by being dragged into courts by those who are seeking to challenge the regulatory and enforcement measures undertaken by a coastal state within the economic zone. ${ }^{14}$

This is the single point challenged by Stevenson \& Oxman in their preceding article on the Geneva session. For the rest they defer to Mr. Adede, but here they argue:

Attempts were made at Geneva to exclude the economic zone as a whole from compulsory dispute settlement. These attempts were strongly, widely, and properly resisted....

This is not a peripheral or procedural issue; it is substantive. If states cannot resort to international adjudicatory procedures to protect their rights, they are ultimately faced with the same problems arising from unilateral treaty interpretation that arise from unilateral claims. ${ }^{15}$

Sohn and Stevenson \& Oxman, then, seem to promote "effective dispute settlement procedures," while Adede stresses the need to protect coastal states from "constant harassment by being dragged into court." Is Article 18 a 
battleground between the maritime powers and the coastal states? If so. how does the military activities exception fit in, for does it not, on its face, tend to favor navies and thus naval powers?

Historically, military exceptions to general rules of the law of the sea have cut both ways, sometimes favoring naval powers, sometimes favoring coastal states. This two-sided nature is easily seen in the treatment of "The Legal Regime of Warships" in C. John Colombos's classical text on the law of the sea. ${ }^{16}$ Colombos shows that, in times of peace, naval operations have been subject to both greater and lesser coastal state regulation than nonmilitary operations. He feels that coastal states have special power to exclude warships from their waters:

Although both the Institute of International Law and the International Law Association grant on principle the right of passage through territorial waters to public as well as private vessels, a distinction ought to be drawn between warships and merchant vessels. The reason for granting this right to merchant vessels is mainly that sea navigation ought to be free and that trade communications should not be interrupted between the various parts of the world. In the case of warships, this reason is lacking. Moreover, the presence of powerful warships in territorial waters and only three miles distant from shore may prove a serious danger to small nations. It is, therefore, reasonable to concede to a State the right to enact regulations regarding the passage of foreign warships through its territorial waters. if considerations based on its safety and protection justify it. ${ }^{17}$

The 1958 Convention on the Territorial Sea and Contiguous Zone's Article 23 also makes a special case of warships:

If any warship does not comply with the regulations of the coastal State concerning passage through the territorial sea and disregards any request for compliance which is made to it, the coastal State may require the warship to leave the territorial sea. ${ }^{18}$

Liere, then, is an example of a military exception. albeit not to dispute settlement, which cuts against the naval power and for the coastal state.

of course, military exceptions to maritime law may favor the naval power. Colombos expresses the familiar doctrine of sovereign immunity:

The general doctrine is, therefore, that a warship remains under the exclusive jurisdiction of her flag-State during her entry and stay in foreign ports and waters. No legal proceedings can be taken against her either for recovery of possession or for damages for collision or for a salvage reward, or for any other cause, and no official of the territorial State is permitted to board the vessel against the wishes of her commander. ${ }^{19}$ 
There are numerous examples of such immunity exceptions to maritime treaties. The Brussels Convention of 1910, for example, concerning Collisions at Sea provides in Article 11:

This convention does not apply to ships of war or to Government ships appropriated exclusively to a public service. ${ }^{20}$

And the Brussels Convention of 1926 which subjected most state-owned ships of ratifying countries to the same rules of liability as pertained to privately-owned vessels stated in Article III:

The provisions of the two preceding Articles shall not apply to ships of war, state-owned yachts, patrol vessels, hospital ships, fleet auxiliaries, supply ships and other vessels owned or operated by a State and employed exclusively at the time when the cause of action arises on Government and non-commercial service, and such ships shall not be subject to seizure, arrest or detention by any legal process, nor to any proceedings in rem. ${ }^{21}$

Two modern examples of the military immunity exception to maritime rules are particularly interesting because the treaties contain provision for dispute settlement. The London Convention of 1973, the International Convention for the Prevention of Pollution from Ships, which was drafted under the auspices of the Inter-Governmental Maritime Consultative Organization, provides in Article 3, Section 3:

The present Convention shall not apply to any warship, naval auxiliary or other ship owned or operated by a State and used, for the time being, only on government noncommercial service. However, each Party shall ensure by the adoption of appropriate measures not impairing the operations or operational capabilities of such ships owned or operated by it, that such ships act in a manner consistent, so far as is reasonable and practicable, with the present Convention.22

The Helsinki Convention of 1974, the Convention on the Protection of the Marine Environment of the Baltic Sea Area, adds aircraft but has identical wording in its Article $4 .{ }^{23}$ Very similar wording regarding pollution is also to be found in Part III, Article 42 of the Informal Single Negotiating Text:

The provisions of Chapters Six and Seven shall not apply to any warship, naval auxiliary or other vessel owned or operated by a State and used, for the time being, only on government noncommercial service. However, each State shall ensure by the adoption of appropriate measures not impairing the operations or operational capabilities of such vessels or other craft owned or operated by it, that such vessels or other craft act in a manner consistent, so far as is reasonable and practicable, with Chapters Six and Seven. ${ }^{24}$ 
Although the 1958 Convention on the Territorial Sea and Contiguous Zone did not mention immunity for warships, the Informal Single Negotiating Text in Part II, Article 31 provides that:

Subject to articles 29,30 , and 32 , nothing in these provisions affects the immunities which warships enjoy under these provisions or other rules of international law. ${ }^{25}$

Does the military activities exception of the Informal Single Negotiating Text more closely resemble the exceptional power of the coastal state to exclude warships from territorial waters; or does Article 18, Section 2(c) more closely resemble the traditional sovereign immunity of warships? In short, does the clause tend to favor the coastal state or the naval power? Neither? Both? Earlier drafts of the clause indicate that it was probably first conceived as a boon to the naval powers. Alternative B.1's (e) and Alternative B.2's (d) read:

Disputes concerning military activities [unless the State conducting such activities gives its express consent]. ${ }^{26}$

The bracketed provision points to the fact that it would be the naval power which would normally oppose dispute settlement procedures.

Another indication that what was meant to be protected here was sovereign immunity is the deleted provision, B.1 (d) and B.2 (c):

Disputes concerning vessels and aircraft entitled to sovereign immunity under international law, and similar cases in which sovereign immunity applies under international law. ${ }^{27}$

Article 18, Section 2(c) does refer to "Government vessels and aircraft engaged in noncommercial service," 28 but this only includes those engaged in "military activities," e.g., those doing military research. Article 18, Section 2(c) is the only surviving sovereign immunity section.

But can we trust to good intentions? Once included, for whatever reason, does Article 18, Section 2(c) tend to benefit the naval power and not the coastal state? Not necessarily. If the naval power is generally satisfied with the provisions of the Law-of-the-Sea Convention as a whole, as they pertain to naval operations, then it is probably the coastal state that benefits from the military activities exception. If the coastal state decides that the Convention gives the naval power too much mobility in its territorial sea or exclusive economic zone, it can choose to elect Article 18, Section 2(c). In this case, the coastal state could interfere with the naval operations of the naval power but the naval power could not bring the coastal state to compulsory dispute settlement. This would 
be no great detriment for the naval power if it was in a position to exert its relative physical advantage, but, if for one of a great variety of possible reasons, it was restrained from doing so, the naval power would effectively forfeit the beneficial terms of the Law-of-the-Sea Convention. This, the next section argues, is precisely the position of the United States.

\section{The Military Activities Exception} and United States Ocean Policy

In order to judge the value of the military activities exception for the United States it is necessary to evaluate the naval implications of the prospective Law-of-the-Sea Convention. For this purpose the Informal Single Negotiating Text is a good guide, for the articles of the Text which are most important for the United States Navy seem, with one exception, to be some of those which are most settled and nearest to becoming the new law of the sea. Official U.S. naval policy sets out four missions for the Navy: strategic deterrence, sea control, projection of power ashore, and naval presence. ${ }^{29}$ A fifth mission, scientific research, is also very important to the navy and might be added to the list. The law-of-the-sea issues most crucial for these five missions relate to rights of navigation and research.

Perhaps the most important issue for the navy is passage through straits. Some 121 straits, including such key waterways as Gibraltar, Dover, and Malacca, fall within 12-mi, though not $3-\mathrm{mi}$, territorial seas. ${ }^{30}$ Traditional international law provides only a right of innocent passage through straits covered by territorial waters. Not only, according to Colombos, are states bordering straits "entitled to take all precautions required for its security" in these waters, ${ }^{31}$ but the 1958 Geneva Convention on the Territorial Sea and Contiguous Zone requires submarines to navigate on the surface and to show their flags. ${ }^{32}$ Furthermore, innocent passage includes no right of overflight. Innocent passage regimes for those 121 new straits would have important consequences for all four U.S. naval missions. With regard to strategic deterrence, innocent passage regimes would have a greater effect upon the navy's carrier-based nuclear weapons than its SSBN fleet (nuclear submarines armed with inter-continental ballistic missiles). A study by Professor Robert E. Osgood has demonstrated that, because of the increasing range of their missiles, innocent passage regimes

although imposing some hardships on the operations of the U.S. SSBN fleet, would not seriously weaken its contribution to nuclear deterrence. ${ }^{33}$

But U.S. carrier-based nuclear weapons in the Mediteranean and the Indian Ocean would be seriously affected by restrictive regimes for Gibraltar and 
Malacca. These forces are a visible show of the U.S. commitment "to deter all out attack on the United States or its allies." ${ }^{34}$ If straits states such as Spain and Morocco, Indonesia and Malaysia were able to restrict the movement of U.S. carrier forces for reasons of their own determinations of national security, the effectiveness of the U.S. nuclear commitment could be threatened especially in times of crisis, precisely the time when straits states would be under the most pressure, internal and external, to limit passage. New innocent passage regimes could also adversely affect the other three U.S. naval missions. This can most easily be seen by looking at the operations of the Navy's Sixth Fleet in the Mediterranean. The only reasonable access for the Sixth Fleet is through the Straits of Gibraltar; Suez is too far from United States home ports and under the control of a state not always friendly to U.S. interests. Since its formation and deployment in 1948, the Six th Fleet has not only provided an important part of the U.S. strategic deterrent, but has been active in all three of the more conventional roles. ${ }^{35}$ It has been instrumental in the control of sea lanes, for example, during the $1973 \mathrm{Arab}$-Israeli War with the resupply of Israel. If passage through Gibraltar had been restricted then, there is more than a reasonable chance that the straits states, under oil pressure, would have limited U.S. shipping and overflight intended for Israel. The Sixth Fleet has also projected power ashore, for example, during the 1958 Lebanon crisis. And the Six th Fleet has always been perceived as a crucial U.S. naval presence, demonstrating United States support for the North Atlantic Treaty Organization and for friendly states in the Middle East. Discretionary rights for coastal states over Gibraltar not only would increase any doubts about the U.S. commitment and ability to act in the Mediterranean, but it would put new pressure on the straits states to limit U.S. naval operations in the sea. The strait next to Gibraltar in importance are Malacca and the other Indonesian straits. These cut more than a week of transit time in the passage of ships from the Pacific to the Indian Ocean. Both the United States and Soviet naval presence in the Indian Ocean is growing. ${ }^{36}$ Although the wisdom of the naval presence is hotly disputed both in the United States and out, insofar as it has been decided to maintain a presence in the Indian Ocean, the conventional as well the strategic missions of the Navy will be affected by the regime of the Indonesian straits.

What then are the interests of the United States in naval passage through straits, and do the provisions of the Informal Single Negotiating Text satisfy the interests? The naval interest is clearly to maintain a right of passage through international straits for naval forces that can not be limited, especially in a time of crisis, by the straits state. Although the Navy would probably have the physical capacity to transit Gibraltar or the Indonesian straits if opposed, the narrow waters of a strait are excellent for the assertion of power by a weaker navy which can then use both land-based air and gun power as well as shore- 
based patrol boats to good advantage. In any event, in a crisis situation, the United States or any country strives to reduce hostility of otherwise uninvolved third parties, including coastal states or states which might sympathize with coastal states or complain of naval passage. Part II, Articles 34-43 of the Informal Single Negotiating Text establish a new right called transit passage which appears to satisfy the Navy's need. ${ }^{37}$ The vital rule in Article 38 which provides that in international straits (which would include Gibraltar and the Indonesian straits) "all ships and aircraft enjoy the right of transit passage, which shall not be impeded." 38 The transit passage articles sensibly strike a balance between the important interests of the straits state in the safety of navigation and the prevention of pollution ${ }^{39}$ and the need of flag states for unimpeded passage. Article 43 reads:

A Strait State shall not hamper transit passage and shall give appropriate publicity to any danger to navigation or overflight within or over the strait of which it has knowledge. There shall be no suspension of transit passage. ${ }^{40}$

Unlike the innocent passage rules, the proposed rules for transit passage permit the passage of aircraft ${ }^{41}$ and make no requirement for submarines to pass on the surface. These are two importance improvements for the Navy.

The naval implications of the transit passage provisions of the Informal Single Negotiating Text are, therefore, very favorable. The United States has often insisted that there could be no satisfactory law-of-the-sea treaty without a comparable provision. John Norton Moore, the Chairman of the Inter-Agency Task Force on the Law of the Sea, expressed this insistence at the Caracas session of the Law-of-the-Sea Conference in 1974:

The U.S. delegation has stated on numerous occasions the central importance that we attach to a satisfactory treaty regime of unimpeded transit through and over straits used for international navigation. Indeed for states bordering as well as states whose ships and aircraft transit such straits, there could not be a successful Law-of-the-Sea Conference unless this question is satisfactorily resolved. ${ }^{42}$

Why should the United States insist on such a transit provision only to have the same problems arise from unilateral treaty interpretation that arise from unilateral claims (to borrow the language of Stevenson \& Oxman for a different purpose) $?^{43}$ Why permit the straits states to interpret, if they care to, transit passage to mean something very close to innocent passage and to decide that United States naval passages violate Part II, Article 39, Section 1?:

Ships and aircraft, while exercising the right of transit passage shall:

(a) proceed without delay through the strait; 
(b) refrain from any threat or use of force against the territorial integrity or political independence of a strait State or in any other manner in violation of the Charter of the United Nations;

(c) refrain from any activities other than those incident to their normal modes of continuous and expeditious transit unless rendered necessary by force majeure or by distress. ${ }^{44}$

Certainly it would be preferable for the United States to have the opportunity to refer a disputed passage to arbitration or judicial settlement than to have the passage resisted by force at the time of crisis. When the crisis has ended the legality of the passage can be viewed more coolly by all sides. It would be preferable to establish international standards for transit passage through international dispute settlement than to allow the straits states to make their own unilateral standards. After all, it is such unilateral standards that the United States has striven to avoid by the successful conclusion of a comprehensive law-of-the-sea treaty.

Next to straits, the key issue for U.S. naval interests in the law-of-the-sea negotiations is the width of the territorial sea. Although 12-mi territorial seas would have little effect on any U.S. naval operations other than passage through straits, 200-mi territorial seas, as advocated by some, could radically transform the very nature of naval mobility. These 200 -mi territorial seas would cover at least some $30 \%$ of all ocean surface. ${ }^{45}$ And $200-\mathrm{mi}$ zones would put the Mediterranean, the North Sea, the South China Sea, and the Caribbean within national jurisdictions. ${ }^{46}$ The greater the extent of territorial seas, the lesser the domain in which the United States Navy may transit freely. Although most states seem willing to accept $12-\mathrm{mi}$ territorial seas, it seems very likely that 200-mi Exclusive Economic Zones (EEZ) will be established. The United States and others are worried that these 200-mi EEZs will creep and become territorial seas limiting navigation rights. When the United States announced its willingness to accept 200-mi EEZs at Caracas in 1974, the Chief of the U.S. Delegation, John $\mathbf{R}$. Stevenson, made it clear that this was conditional on the protection of transit rights through the EEZ:

Our willingness and that of many other delegations to accept a 200-mile outer limit for the economic zone depends on the concurrent negotiation and acceptance of correlative coastal state duties.

The coastal rights we contemplate comprise full regulatory jurisdiction over the exploration and exploitation of seabed resources, non-resource drilling, fishing for coastal and anadromous species, and installations constructed for economic purposes.

The rights of other states include freedom of navigation, overflight, and other non-resource uses. ${ }^{47}$ 
If the EEZ crept to include the right to govern transit, the naval implications would be dangerous. The operations of the Sixth Fleet in the Mediterranean and those of the Seventh Fleet in the South China Sea would be within the waters of numerous coastal states. Depending on their attitude to the United States and their own determinations of their security, the coastal states could attempt to use innocent passage rules for these waters and exclude U.S. naval operations. Such an attempt would either force the Navy from these areas, thereby diminish. ing the U.S. commitment, or lead to unnecessary and tension-building confrontations between the United States Navy and coastal forces. Naval passage along the west coast of Africa, which might be necessary in some circumstances to protect vital shipping lanes would entail transit across more than 20 African EEZs. If each state could choose different rules for passing vessels, the result would be confusion and, again, possible conflict. Obviously, the United States naval interest in the regime of territorial waters and EEZs calls for rights of transit unimpeded by unilateral coastal state claims. The right to research in the EEZ is also in the U.S. naval interest.

The Informal Single Negotiating Text provides in Part II, Articles 45-61, for a regime which could well satisfy the U.S. naval transit interest. ${ }^{48}$ Although it does not recognize that the EEZ is high seas with special economic rights for the coastal state, it does establish in Article 47, Section 1 that:

All states, whether coastal or land-locked, shall, subject to the relevant provisions of the present Convention, enjoy in the exclusive economic zone the freedoms of navigation and overflight and of the laying of submarine cables and pipelines and other internationally lawful uses of the sea related to navigation and communication. ${ }^{49}$

Vital here is the establishment of the "freedom" of navigation. Article 46 limits the EEZ to 200 nautical mi ${ }^{50}$ and beyond that Part II, Article 75 provides for "freedom of navigation" on the remaining high seas. ${ }^{51}$ Importantly, too, the limit to the territorial sea is set at 12 nautical mi by Part II, Article $2 .{ }^{52}$ Altogether, these provisions tend to protect the freedom of navigation for warships and the right of overflight for aircraft beyond a 12-mi territorial limit. As such, this would be a satisfactory resolution for U.S. naval interests. Coastal states may, however, attempt to use the broad grants of power in the EEZ to restrict naval transit. There is more to fear from unilateral coastal state claims than there is from the rules in the Informal Single Negotiating Text. Once again, it would seem that the Navy is better served by relying on the Law-of-the-Sea Convention and on dispute settlement procedures than on the give and take of the development of customary law by claim and counterclaim, action and counteraction. 
A potential draw-back of a convention based on the Informal Single Negotiating Text for the Navy is Article 45, Section 1(b)(ii), which gives the coastal state the exclusive right to regulate scientific research in the EEZ. The freedom of research is still in hot dispute in the law-of-the-sea negotiations and a more favorable clause may eventually surface. Even if one did not, this restriction would have to be balanced against the otherwise generally favorable provisions of the territorial sea and EEZ provisions and against the facts that many of our allies, e.g., Canada, Australia, and Japan, would have some of the largest EEZs and that Soviet naval research would be significantly more impeded than our own.

Should the United States, then, support or oppose the retention of the military activities exception? The analysis would tend to show that the United States should oppose the mere inclusion of the exception. No matter that Article 18 , Section 2(c) was probably first visualized as a concession to the naval powers, a recognition of sovereign immunity. The exception takes on an entirely different complexion when included in the dispute settlement part. If a sovereign immunity clause is included in the substantive body of a convention as it was in the 1973 London Convention and the 1974 Helsinki Convention or as it is in Part II, Article 31, or Part III, Article 42, of the Informal Single Negotiating Text, then it is truly a concession to sovereign immunity. But as an exception to dispute settlement procedures it has the effect of removing naval operations from the protection of impartial settlement and leaving them up to dispute by unilateral coastal state claims. Although intended to be exercised by the naval powers, Article 18, Section 2(c) could be chosen by coastal states which intend to apply their own definitions of permissible naval conduct to naval passage through straits or through territorial seas and economic zones. In crucial waters, these coastal state definitions could well be more restrictive than commonly accepted standards likely to be applied in arbitration or dispute settlement. Considering the favorable nature of the Informal Single Negotiating Text with regard to issues of importance to United States naval operations, the United States would be better off trusting to the new Law-of-the-Sea Convention and dispute settlement procedures than to unilateral determinations of legal naval conduct.

But if the military activities exception is retained, should the United States elect it when ratifying the Law of the Sea Convention? The answer here again is no. Article 18, Section 5 provides:

Any Contracting Party which has made a declaration under paragraph 2 shall not be entitled to invoke any procedure excepted under such declaration in relation to any excepted category of dispute against any other Contracting Party. ${ }^{53}$ 
Thus, if the United States elects the military activities exception, the United States will be unable to go into compulsory dispute settlement in any dispute involving U.S. naval forces. If, for example, straits states resist U.S. naval passage through Gibraltar or through the Indonesian straits, or if a coastal state should claim that the operations of the United States Sixth or Seventh fleets in its EEZ threaten the security of that state, the United States would be unable to resort to arbitration or judicial settlement for a resolution of the dispute because this country had declared for Article 18, Section 2(c). By electing this exception the United States would be forfeiting an attractive and peaceful way of settling maritime disputes concerning naval operations. A similar forfeiture has resulted from the Connally Amendment reservation to the jurisdiction of the Interna. tional Court of Justice. ${ }^{54}$

The potential mischief of the military activities exception is great. Naval operations have been and will likely remain one of the most controversial exercises of U.S. ocean power. As the United States reduces its military commitments on land, it is likely to increasingly rely on ocean forces to maintain the U.S. commitment to other countries and to act when necessary. As the Soviet Navy grows, the possibilities of U.S./Soviet ocean confrontation increase and it is more likely that states will venture to keep both superpower naval forces far from their shores. Article 18, Section 2(c), by removing military activities from dispute settlement procedures, removes one sort of activity almost certainly in need of peaceful resolution.

\section{Acknowledgement}

The author owes a debt of gratitude to Louis B. Sohn for his gracious advice and good counsel.

\footnotetext{
Notes

${ }^{1}$ Informal Single Negotiating Text, U.N. Docs, A/CONF.62/WP.8/Part I, A/CONF.62/WP.8/ Part II, A/CONF.62/WP.8/Part III, A/CONF.62/WP.9 (1975).

2 John R. Stevenson and Bernard H. Oxman, "The Third United Nations Conference on the Law of the Sea: The 1975 Geneva Session," 69 American Journal of International Law 763-764 (1975).

${ }^{3}$ Informal Single Negotiating Text, U.N. Doc. A/CONF.62/WP.8/Part I, at 1.

${ }^{4}$ John R. Stevenson and Bernard H. Oxman, "The Preparations for the Law of the Sea Conference," 68 American Journal of International Law 1 (1974); John R. Stevenson and Bernard H. Oxman, "The Third United Nations Conference on the Law of the Sea: The 1974 Caracas Session," 69 American Journal of International Law 1 (1975); and Stevenson \& Oxman, supra note 2.

${ }^{5}$ Louis B. Sohn, "Settlement of Disputes Arising Out of the Law of the Sea Convention," 12 San Diego Law Review 495 (1975); and A. O. Adede, "Settlement of Disputes Arising Under the Law of the Sea Convention," 69 American Journal of International Law 798 (1975).

'Informal Single Negotiating Text, A/CONF.62/WP.9, at 11.
} 
${ }^{7}$ Ibid.

${ }^{8}$ Mark W. Janis, Sea Power and the Law of the Sea (1976).

${ }^{9}$ Sohn, supra note 5 , at 497 , note 9 .

${ }^{10}$ Sohn, ibid., at 513-515; and Adede, supra note 5, at 813-816.

"Sohn, ibid., at 513-514.

12 Ibid.

${ }^{13}$ Adede, supro note 5 , at 814-815.

${ }^{14}$ Ibid., at 815 .

${ }^{15}$ Stevenson \& Oxman, supra note 2 , at 796.

${ }^{16} \mathrm{C}$. John Colombos, The International Law of the Sea, at 221-245 (4th Edition, 1961).

${ }^{17}$ Ibid., at 223.

${ }^{18}$ Convention on the Territorial Sea and the Contiguous Zone, 516 U.N.T.S. 205 (1958).

${ }^{19}$ Colombos, supra note 16 , at 227.

${ }^{20}$ Brussels Convention of 25 th September 1910 , concerning Collisions at Sea, in Philio Manca, International Maritime Law III, at 71 (1970).

${ }^{21}$ Brussels Convention of 10th April, 1926 and Protocol of 24th May, 1934, concerning the Immunity of State-Owned Ships, in Philio Manca, International Maritime Law I, at 111-112 (1970).

${ }^{22}$ International Convention for the Prevention of Pollution from Ships, 12 International Legal Materials 1321 (1973).

${ }^{23}$ Convention on the Protection of the Marine Environment of the Baltic Sea Area, 13 International Legal Materials 548 (1974).

${ }^{24}$ Informal Single Negotiating Text, U.N. Doc. A/CONF.62/WP.8/Part III, at 13.

${ }^{25}$ Informal Single Negotiating Text, U.N. Doc. A/CONF.62/WP.8/Part II, at 13.

${ }^{26}$ Sohn, supra note 5 , at 515 .

${ }^{27}$ Ibid.

${ }^{28}$ Informal Single Negotiating Text, U.N. Doc. A/CONF.62/WP.9, at 11.

${ }^{29}$ Stansfield Turner, "Missions of the U.S.Navy," 26 Naval War College Review 5, at 2-17 (1974).

${ }^{30}$ Office of the Geographer, United States Department of State, "World Straits Affected by a 12-Mi Territorial Sea," (Chart, 1971).

${ }^{31}$ Colombos, supra note 16 , at 170.

${ }^{32}$ Convention on the Territorial Sea and the Contiguous Zone, supra note 18, Article 14, Section 6.

${ }^{33}$ Robert E. Osgood, "U.S. Security Interests in Ocean Law," 2 Ocean Development and International Law 1, at 17 (1974).

${ }^{34}$ Turner, supra note 29 , at 5 .

${ }^{35}$ P. A. Dur, "The U.S. Sixth Fleet: Search for Consensus," 100 Noval Institute Proceedings 4, at 18-23 (1974).

${ }^{36}$ D.C.F. Daniel, "Naval Presence and National Interests: The Case of the United States Navy in the Indian Ocean," Naval Postgraduate School paper presented to the Western Political Science Association, March 20, 1975, Seattle.

${ }^{37}$ Informal Single Negotiating Text, U.N. Doc. A/CONF.62/WP.8/Part II, at 15-18.

${ }^{38}$ Ibid., at 15.

${ }^{39}$ Ibid., articles 40 and 41 , at 16-17.

${ }^{40}$ Ibid., at 18.

${ }^{41}$ Ibid., Article 38, at 15. 
42 John Norton Moore, "Statement before Committee II, Monday, July 22, 1974," Department of State Press Release, at 1 (1974).

${ }^{43}$ Stevenson \& Oxman, supra note 2, at 796.

${ }^{44}$ Informal Single Negotiating Text, U.N. Doc. A/CONF.62/WP.8/Part II, at 16.

${ }^{45}$ Arvid Pardo, "A Statement on the Future of the Law of the Sea in Light of Current Trends in Negotiations," 1 Ocean Development and International Law 315, at 332 (1974). ${ }^{46}$ Office of the Geographer, United States Department of State, "Global Effect of 200-Mile Nautical Mile Territorial Sea Claims," (Chart, 1971).

${ }^{47}$ John R. Stevenson, "Address before the Plenary Session of the Law of the Sea Conference, Caracas, Venezuela, July 11, 1974," Department of State Press Release, at 9 (1974).

${ }^{48}$ Informal Single Negotiating Text, U.N. Doc. A/CONF.62/WP.8/Part II, at 19-26.

${ }^{49}$ Ibid., at 19.

${ }^{50}$ Ibid.

${ }^{51}$ Ibid., at 30 .

s2 lbid., at 5 .

${ }^{53}$ Informal Single Negotiating Text, U.N. Doc. A/CONF.62/WP.9, at 12.

${ }^{54}$ Leo Gross, "Bulgaria Invokes the Connally Amendment," 56 American Journal of International Law 357 (1962). 
